\title{
ANATOMICAL AND PHYSIOLOGICAL MODIFICATIONS OF MICROPROPAGATED 'CAIPIRA' BANANA PLANTS UNDER NATURAL LIGHT
}

\author{
Frederico Henrique da Silva Costaㄹ ${ }^{1}$ Moacir Pasqual2*; Jonny Everson Scherwinski Pereira ${ }^{3}$; \\ Evaristo Mauro de Castro ${ }^{1}$ \\ ${ }^{I}$ UFLA - Programa de Pós-Graduação em Fitotecnia. \\ ${ }_{3}^{2}$ UFLA/Depto. de Fitotecnia, C.P. 3037 - 37200-000 - Lavras, SP - Brasil. \\ ${ }^{3}$ Embrapa Recursos Genéticos e Biotecnologia, Parque Estação Biológica - PqEB, Av. W5 Norte (final), C.P. \\ 02372 - 70770-000 - Brasilia, DF - Brasil. \\ *Corresponding author <mpasqual@ufla.br>
}

ABSTRACT: Research about the use of natural light associated to changes in sucrose levels demonstrated potential in promoting in vitro hardiness of tropical climate species, as well as reducing production costs. However, little is known about physiological and structural changes that happen in the process. This study evaluated the physiological and anatomic performance, and ex vitro survival of micropropagated banana plants in response to cultivation conditions, in the stage of in vitro rooting. Shoots of the 'Caipira' cultivar were cultivated in MS medium, supplemented with $1 \mathrm{mg} \mathrm{L}^{-1} \mathrm{NAA}$ and $6 \mathrm{~g}$ $\mathrm{L}^{-1}$ agar, in which the following treatments were applied: two sucrose concentrations $\left(15 \mathrm{~g} \mathrm{~L}^{-1}\right.$ or $\left.30 \mathrm{~g} \mathrm{~L}^{-1}\right)$ and two cultivation conditions (Natural light - greenhouse and Artificial light - growth chamber). At the end of 45 days, the contents of chlorophyll $a, b$ and total, the relative water content in the tissues, anatomic characteristics and the ex vitro survival were evaluated. Effects of growth environment and sucrose concentration were observed on micropropagated 'Caipira' banana anatomy, physiology and survival. In vitro rooting of the shoots under natural light in the medium containing $15 \mathrm{~g} \mathrm{~L}^{-1}$ or $30 \mathrm{~g} \mathrm{~L}^{-1}$ sucrose promoted major alteration in the increase of palisade and spongy parenchyma, as well as reducing leaf water loss and plant death. The results obtained in the present study confirm the potential of the use of natural light as a substitute for artificial light for micropropagation of tropical species. Key words: Musa spp., solar light, carbohydrate, water loss, anatomy

\section{MODIFICAÇÕES ANATÔMICAS E FISIOLÓGICAS DE BANANEIRAS 'CAIPIRA' MICROPROPAGADAS SOB LUZ NATURAL}

\begin{abstract}
RESUMO: Pesquisas acerca do uso da luz natural associado a alterações nos níveis de sacarose têm apresentado potencial para promover a rustificação in vitro de espécies de clima tropical bem como reduzir os custos de produção. Todavia, pouco se conhece sobre as modificações fisiológicas e estruturais ocasionadas. Avaliaram-se o comportamento fisiológico, anatômico e a sobrevivência ex vitro de bananeiras micropropagadas em resposta às condições de cultivo, na fase de enraizamento in vitro. Para isso, brotações axilares da cultivar Caipira foram cultivadas em meio MS, adicionado de ANA $\left(1 \mathrm{mg} \mathrm{L}^{-1}\right)$ e agar $\left(6 \mathrm{~g} \mathrm{~L}^{-1}\right)$, onde foram aplicados os seguintes tratamentos: duas concentrações de sacarose $\left(15 \mathrm{~g} \mathrm{~L}^{-1}\right.$ e $\left.30 \mathrm{~g} \mathrm{~L}^{-1}\right)$ e dois ambientes de cultivo (Luz natural - casa de vegetação e Luz artificial - sala de crescimento). Ao final de 45 dias, foram avaliados os teores de clorofila $a, b$ e total, conteúdo relativo de água nos tecidos, características anatômicas e a sobrevivência ex vitro. Houve efeito do ambiente de cultivo e concentrações de sacarose sobre a anatomia, fisiologia e sobrevivência de plantas de bananeira 'Caipira' micropropagada. O enraizamento in vitro das brotações sob luz natural e meio contendo $15 \mathrm{~g} \mathrm{~L}^{-1}$ ou $30 \mathrm{~g} \mathrm{~L}^{-1}$ de sacarose promove como principais alterações o aumento na espessura dos parênquimas paliçádico e esponjoso, bem como reduz a perda de água foliar e morte de plantas. Os resultados alcançados no presente estudo confirmam o potencial da luz natural em substituir a iluminação artificial para a micropropagação de espécies tropicais.

Palavras-chave: Musa spp, luz solar, carboidrato, perda de água, anatomia
\end{abstract}

\section{INTRODUCTION}

In vitro propagation has been extensively used as an alternative and efficient method for quick propagation of several plant species (Hazarika, 2006). In banana, the application of this technology has enabled the 
fast diffusion and validation of new genotypes, consisting on the basis for the recovery of propagated material with high phytosanitary standard (Gübbük \& Pekmezci, 2004).

Despite of its importance, micropropagation under heterotrophic conditions is responsible for the induction of plant's physiological and structural modifications, considered as different from that obtained in $e x$ vitro plants (Yokota et al., 2007), such as low regulation mechanism of water loss, mainly due to inefficient stomata functionality and the formation of epicuticular wax (Lamhanedi et al., 2003), and reduced development of photosynthetic tissues (Amâncio et al., 1999).

Some strategies have been adopted, such as reduction of carbohydrate level and relative humidity inside the flasks (Mohammed \& Vidaver, 1990), variations on irradiancy levels (Navarro et al., 1994), use of natural light (Kodym \& Zapata-Arias, 1999; Talavera et al., 2005) and the increase in gas exchange (ValeroAracama et al., 2007). Light is considered to be one of the most important due to the decisive influence on plant development. Light enables the photostimulation of the biosynthesis of compounds necessary for growth (Larcher, 2000) or promotes structural modifications needed for better plant adaptation to the external environment (Whatley \& Whatley, 1982). Nevertheless, studies include only few species, mainly using the natural light as an alternative to the illumination with fluorescent bulbs, but without evaluating the effects on plant morphology and physiology. Thus, the objective in this study was to evaluate the physiological and anatomic performance, and ex vitro survival of micropropagated banana plants in response to the cultivation conditions, in the stage of in vitro rooting.

\section{MATERIAL AND METHODS}

This study was carried out in Lavras $\left(21^{\circ} 14^{\prime} \mathrm{S}\right.$, $45^{\circ} 17^{\prime} \mathrm{W}$ and $918 \mathrm{~m}$ asl), MG, Brazil, from March to July 2006. The plant material consisted of Musa cv. Caipira (AAA) shoots $(2-3 \mathrm{~cm}$ and two expanded leaves), obtained from the in vitro establishment and multiplication of shoot tips of elite plants.

MS medium (Murashige \& Skoog, 1962), containing $5 \mathrm{mg} \mathrm{L}^{-1} \mathrm{BA}$ (6-Benzylaminopurine) was used to obtain the explants, and subculturing was carried out at 35 days interval. Standard growth conditions were $25 \pm 2^{\circ} \mathrm{C}$ and 16 hours irradiance at $35 \mu \mathrm{mol} \mathrm{m} \mathrm{m}^{-2}$. Subsequently, the explants were transferred to culture medium composed of salts and vitamins used in the MS medium, containing $1 \mathrm{mg} \mathrm{L}^{-1}$ NAA ( $\alpha$-naphthalene acetic acid), in which the treatments for in vitro rooting/elongation were applied, during 45 days. The treatments were analyzed in a $2 \times 2$ factorial design, and were composed of sucrose concentrations (15 g $\mathrm{L}^{-1}$ or $30 \mathrm{~g} \mathrm{~L}^{-1}$ ) and culturing environments (greenhouse - natural light, and growth chamber - artificial light). All the tested media were solidified with $6 \mathrm{~g} \mathrm{~L}^{-1}$ agar, and the $\mathrm{pH}$ adjusted to $5.8 \pm 0.1$ before the addition of the solidifying agent. Cultivation was carried out in 250-mL flasks containing $40 \mathrm{~mL}$ of medium and closed with clear plastic film. At the end of 45 days, the following parameters were evaluated: survival percentage, chlorophyll contents, relative water content and anatomical characteristics.

The artificial light environment consisted of a growth chamber, with lighting provided by two cool white fluorescent bulbs (Osram $20 \mathrm{~W}$ each) $(16 \mathrm{~h}$ irradiance at $35 \mu \mathrm{mol} \mathrm{m}^{-2} \mathrm{~s}^{-1}$ ) at $25 \pm 2{ }^{\circ} \mathrm{C}$, while the natural light environment corresponded to a greenhouse, covered by a clear polyethylene film (150 microns) and $70 \%$ shading, having the following environmental parameters: maximum, minimum and average temperature of $26^{\circ} \mathrm{C} / 32^{\circ} \mathrm{C} ; 16^{\circ} \mathrm{C} / 16^{\circ} \mathrm{C}$ and $20^{\circ} \mathrm{C} / 23^{\circ} \mathrm{C}$, and maximum, minimum and average levels of irradiance of $432.17 \mu \mathrm{mol} \mathrm{m} \mathrm{m}^{-2} / 918.57 \mu \mathrm{mol} \mathrm{m} \mathrm{m}^{-2} ; 51.20 \mu \mathrm{mol}$ $\mathrm{m}^{-2} \mathrm{~s}^{-1} / 49.04 \mu \mathrm{mol} \mathrm{m}^{-2} \mathrm{~s}^{-1}$ and $227.15 \mu \mathrm{mol} \mathrm{m}^{-2} \mathrm{~s}^{-1} /$ $457.38 \mu \mathrm{mol} \mathrm{m} \mathrm{m}^{-2} \mathrm{~s}^{-1}$, corresponding to cloudy and clear days typical of the experimentation period. The data of diurnal solar irradiance, incident at the top of the flasks, were obtained by irradiance sensors (LI-200SA, Li-cor, Lincoln, Nebrasca, USA), connected to a recording system (LI 1400; Li-cor, Neb.), with readings occurring at 30-minute intervals for 11 hours (from 7:00 AM to 6:00 PM). At the artificial environment, irradiance was measured only during $6 \mathrm{~h}$, because the environmental conditions were rigorously controlled. Data corresponding to the weekly temperature means were obtained with a thermohygrograph.

Chlorophyll contents determination was carried out randomly in five plants per treatment. Fifty milligram samples were collected from the first completely expanded leaf, at the center of the leaf blade, and were immediately wrapped in aluminum foil and placed in an ice box. Extraction and quantification of chlorophyll a, $\mathrm{b}$ and total was carried out as described by Arnon (1949), reading the extracts in a spectrophotometer at $663 \mathrm{~nm}$ and $645 \mathrm{~nm}$, respectively, for chlorophyll a and b. Chlorophyll contents, on a fresh mass basis, in $\mathrm{mg} \mathrm{g}^{-1}$, was calculated according to Castro et al. (2005).

The relative water content (RWC) was determined using whole plants. Plants were removed from the growth flasks, subjected to a quick root rinse and gently blotted dry. Subsequently, they were placed on a bench top, over aluminum foil, and maintained at room temperature (about 63\% relative moisture). Every ten minutes, for 240 minutes, six plants per treatment were weighed to determine the fresh mass. Sub- 
sequently, the dry mass of the leaves was ALSO obtained $\left(50^{\circ} \mathrm{C}\right)$ and the RWC for each time was estimated as: $\mathrm{RWC}(\%)=\left[\left(\mathrm{FW}_{\mathrm{t}}-\mathrm{DW}\right) /\left(\mathrm{FW}_{\mathrm{s}}-\mathrm{DW}\right)\right] \mathrm{x}$ 100 , where $\mathrm{FW}_{\mathrm{t}}$ is the fresh matter at time $\mathrm{t}, \mathrm{FW}_{\mathrm{s}}$ is the initial fresh matter (time zero) and DW is the dry matter (Romano \& Martins-Loução, 2003).

Anatomic evaluations were carried out on the central part of the second expanded leaf, obtained from different plants per treatment. Plant material was previously fixed in 70 FAA (formaldehyde, acetic acid and ethanol) (Johansen, 1940), during $72 \mathrm{~h}$ and conserved in $70 \%$ ethanol $(\mathrm{v} / \mathrm{v})$. The transversal and paradermal sections were obtained in a microtome and manually, by using a stainless-steel blade. Subsequently, they were subjected to clarification with sodium hypochlorite $(50 \% \mathrm{v} / \mathrm{v})$, rinsed three times in distilled water, stained with astra-safranine blue (transversal) and safranine $1 \%$ (paradermal), and mounted in water-glycerol for microscope observation (Kraus \& Arduin, 1997). Transversal sections were observed in a Kena-vision 2100 light microscope, where the width of the epidermis and hypodermis (upper and lower faces), and the spongy and palisade parenchyma, after the fourth lateral leaf bundle sheath, were measured. Additionally, the foliar limb thickness was measured. For stomata characterization, only stomata density (number of stomata $\mathrm{mm}^{-2}$ ) was obtained using an Olympus CBB light microscope (Labouriau et al., 1961).

The acclimatization was carried out in a greenhouse with constant misting. Plants were removed from the flasks, and had their roots washed in tap water and pruned, and were transferred to $0.3 \mathrm{~L}$ root plug containing a mixture of soil and a commercial substrate: carbonized rice husks $(1: 1: 1 \mathrm{v} / \mathrm{v})$, amended with $50 \mathrm{~g} \mathrm{~L}^{-1}$ of humus and $20 \mathrm{~g} \mathrm{~L}^{-1}$ of single superphosphate.

A completely randomized experimental design was used for the quantification of the chlorophyll content and for the anatomical analysis, with five and six replications of tissues measurements and stomata counting. The assay of the RWC was carried out as subdivided plots in time in a completely randomized design, with six replications per treatment. The data obtained were initially submitted to individual analyses of variance (for each cultivation environment), following a test of homogeneity of variances and the combined analyses of the environments, using the software Sisvar 4.3 (Ferreira, 2000) and test F $(p \leq 0.05)$. Plant survival was determined by visual observation.

\section{RESULTS AND DISCUSSION}

\section{Chlorophyll contents}

Differences for chlorophyll $a$ and total, regarding the cultivation environment were found only for the treatment containing $30 \mathrm{~g} \mathrm{~L}^{-1}$ sucrose. At this concentration, high contents of both types of chlorophyll were obtained in conditions of artificial light, with 1.24 $\mathrm{mg} \mathrm{g}^{-1}$ and $1.67 \mathrm{mg} \mathrm{g}^{-1}$ respectively. However, no differences were observed among the concentrations of carbohydrates in both environments $(p \leq 0.05)$ (Table $1)$. This result could be due to the lower irradiance observed in the growth chamber (artificial) environment, because the processes of synthesis and degradation (photo-oxidation) of chlorophylls are directly correlated with irradiance, with pronounced reduction on chlorophyll content (per mass unit and, or area) under high levels (Lee et al., 2000; Atroch et al., 2001; Kitajima \& Hogan, 2003; Deccetti, 2004).

No effects were observed for chlorophyll $b$ and the $a / b$ ratio for all treatments, isolated or in association. This is consistent with the findings of Deccetti (2004) with plants of Amona glabra L., at the in vitro rooting stage, in which lower influence of the increase in irradiance (artificial) levels on $a$ and $b$ chlorophylls was observed. Nevertheless, Lee et al. (2000) observed a reduction in chlorophyll concentrations and in the ratio of chlorophyll $a / b$ by the exposure to a high PFD (Photon Flux Density) in two tree species native to Asia.

\section{Relative water content (RWC)}

A significant interaction of the three factors (Environment $\times$ Sucrose $\times$ Time) evaluated was obtained for the RWC, where greater water loss (lower RWC) with exposition time occurred in plants grown in the artificial environment, and this loss was greater at $30 \mathrm{~g} \mathrm{~L}^{-1}$ sucrose (Figure 1). Lower RWC in plants

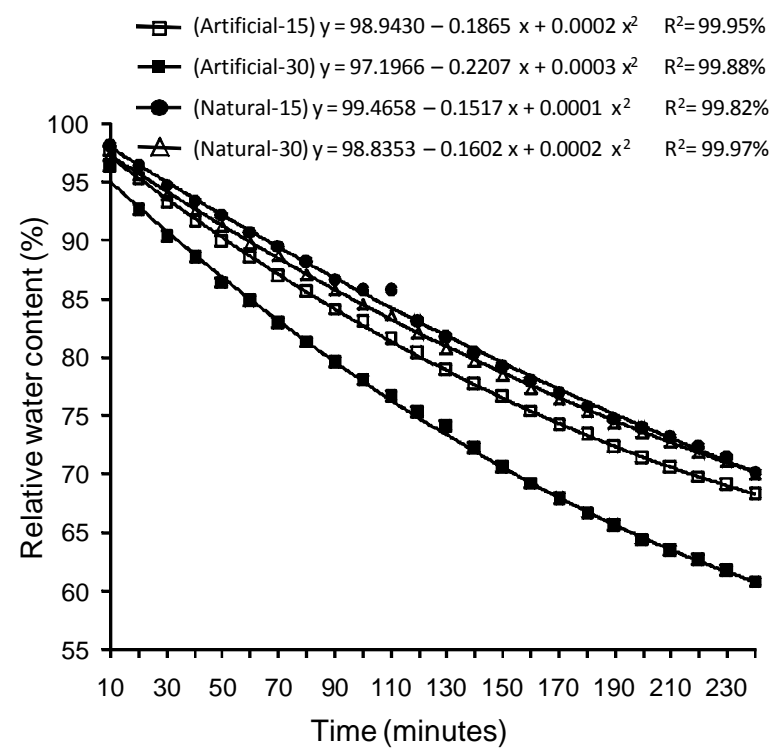

Figure 1 - Relative water contents of in micropropagated 'Caipira' (AAA) banana plants as a function of the cultivation environment and sucrose concentration. 
Table 1 - Chlorophyll $a$ and total contents of micropropagated 'Caipira' (AAA) banana plants as a function of the cultivation environment and sucrose concentration.

\begin{tabular}{|c|c|c|c|c|c|c|}
\hline \multirow{2}{*}{ Sucrose } & \multicolumn{2}{|c|}{ Chlorophyll $a$} & \multirow{2}{*}{ Mean } & \multicolumn{2}{|c|}{ Chlorophyll total } & \multirow{2}{*}{ Mean } \\
\hline & Natural & Artificial & & Natural & Artificial & \\
\hline $\mathrm{g} \mathrm{L}^{-1}$ & $-\cdots$ & 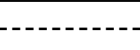 & $\ldots \mathrm{mg}$ & esh mass & - & --------- \\
\hline 15 & $1.05 \mathrm{aA}$ & $1.12 \mathrm{aA}$ & $1.08 \mathrm{a}$ & $1.42 \mathrm{aA}$ & $1.50 \mathrm{aA}$ & $1.46 \mathrm{a}$ \\
\hline 30 & $0.96 \mathrm{aB}$ & $1.24 \mathrm{aA}$ & $1.10 \mathrm{a}$ & $1.34 \mathrm{aB}$ & $1.67 \mathrm{aA}$ & $1.50 \mathrm{a}$ \\
\hline Mean & $1.01 \mathrm{~B}$ & $1.18 \mathrm{~A}$ & & $1.38 \mathrm{~B}$ & $1.59 \mathrm{~A}$ & \\
\hline CV(\%) & \multicolumn{2}{|c|}{8.48} & \multicolumn{3}{|c|}{8.54} & \\
\hline
\end{tabular}

Means followed by distinct letters, small caption in the column and capital in the row, are different ( $\mathrm{F}$ test at $5 \%$ ).

grown under artificial lighting and medium containing $30 \mathrm{~g} \mathrm{~L}^{-1}$ sucrose is observed only when the average of each growth environment and sucrose concentration is evaluated, with $82.6 \%$ and $78.1 \%$ for the natural and artificial conditions, and $81.8 \%$ and $78.9 \%$ for 15 and $30 \mathrm{~g} \mathrm{~L}^{-1}$. Similar results have been observed reported by Decetti (2004) in leaf disks of Amona glabra L., who observed reduced water loss in leaf disks from plants grown under high in vitro irradiance

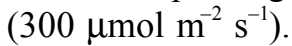

The greatest RWC observed under natural light could have been favored by variations in relative humidity, irradiance and temperature inside the flasks, which would have favored a better response of stomata opening and closing mechanism after plant exposure to the external cultivation conditions, thus favoring the hardening of the plants. This hypothesis is supported by the observations of Silva (2006) with pineapple, who also conducted an experiment in the municipality of Lavras and under the same cultivation, irradiance and temperature conditions. According to Silva (2006), the relative humidity and temperature inside the flasks, under natural light environment, varied from $58 \%$ to $95 \%$ and $10^{\circ} \mathrm{C}$ to $40^{\circ} \mathrm{C}$; however, in the artificial environment they ranged from $96 \%$ to $98 \%$ and $23^{\circ} \mathrm{C}$ to $27^{\circ} \mathrm{C}$. Hazarika (2003) stated that plants developed in vitro under conditions of low relative humidity showed lower transpiration and less ex vitro translocation problems, and the persistent leaves are quite similar to the ones developed naturally.

Sciutti \& Morini (1995) stated that the high relative humidity within the cultivation flasks was the main factor leading to modifications in tissue structure and functioning. According to those authors, the increase in irradiance levels and or reduction in relative humidity during in vitro cultivation have resulted in anatomical modifications similar to those observed during acclimatization in greenhouse, with the increase in deposition of epicuticular wax, reduction on stomata size and density, decreasing the loss of turgor and improving stomata functionality (Capellades et al., 1990; Sciutii \& Morini, 1995; Decceti, 2004).
Moreover, Sciutti \& Morini (1995) stated that Prunus cerasifera plants rooted under $100 \%$ relative humidity lost more water $(p \leq 0.05)$ than plants rooted under relative humidity from $70 \%$ to $80 \%$. In addition, plants grown under relative humidity from $70 \%$ to $80 \%$ presented a visible thicker waxy layer on the leaves, the stomata were closed, not raised and without collapse, even after 30 minutes of exposure in growth chamber. In contrast, under $100 \%$ humidity the stomata were more numerous, raised on the leaf surface, with larger apertures and the epidermal cells collapsed after 30 minutes of exposure. In this aspect, Capellades et al. (1990) reported that it is likely that the collapse of the epidermal cell could cause loss of integrity of the leaf surface, leading to more desiccation.

These results are consistent with those of Khan et al. (1999), where greater water loss was observed in leaves of in vitro Quercus robur plants, with $90 \%$ and $80 \%$ loss in plants obtained in the multiplication and rooting stages, within 30 to $90 \mathrm{~min}$. This was attributed to a high density of stomata and the heterogeneous functionality of the stomata developed in this environment. Similar results about greater water loss in in vitro leaf tissues was observed by Romano \& Martins-Loução (2003), which occurred in leaves developed during the in vitro rooting, compared to the ones formed in the acclimatization stage, losing approximately $53 \%$ and $14 \%$, respectively, in the first 30 minutes when exposed to $50 \%$ of relative humidity at $21 \pm 2{ }^{\circ} \mathrm{C}$. Additionally, the leaves formed in vitro showed opened stomata and collapse of guard-cells, which was not observed in acclimatized plants. High in vitro humidity, resulting from the low gas exchange in the flasks, lead the plants to open their stomata to keep the equilibrium with the atmosphere inside the flask, inducing an abnormal development of stomata, thus remaining opened even when they are subjected to a drastic change in the environment (Shackel et al., 1990; Sutter et al., 1992). 


\section{Anatomical features}

Differences related to sucrose concentration were observed only on the width of the upper epidermis and on the foliar limb, with greater width in the medium amended with $15 \mathrm{~g} \mathrm{~L}^{-1}(p \leq 0.05)$. For the cultivation environments, the plants grown under natural light showed significant thickening in both the palisade and spongy parenchyma, in contrast to the upper and lower epidermis, and lower hypodermis, which had greater thickening in the artificial environment ( $p$ $\leq$ 0.05) (Table 2). Sandoval et al. (1994) found that, despite in vitro 'Grande Naine' banana plants had epidermis and hypodermis with relatively thick cells, they showed thin walls, which could explain the greatest thickenings observed in the present study. As to the parenchyma, the increase in the width of these tissues due to increased irradiance was also observed by Hanba et al. (2002) in in vitro Acer species.

Greater thickening due to increase irradiance levels was also reported by Deccetti (2004). According to that author, Annona glabra plants rooted in vitro at $300 \mu \mathrm{mol} \mathrm{m} \mathrm{m}^{-2} \mathrm{~s}^{-1}$ had increase in the width of the palisade and spongy parenchyma, besides the pronounced differentiation of these tissues, responses that could be determinant to the photosynthetic process and ex vitro survival. The occurrence of more elongated palisade cells consists of classic pattern of response to plant adaptation to greater light intensity, thus highlighting the adaptable plasticity to the new environment (Lee et al., 2000). Moreover, structural modifications related to the development of the photosynthetic tissues could have an important role in increasing photosynthetic activity, survival and acclimatization of plants (Amâncio et al., 1999; Serret \& Trillas, 2000.

As to the upper hypodermis, greater thickening $(p \leq 0.05)$ was observed in plants grown under artificial light environment, in both sucrose concentrations (Table 3). Greater width of the lower and upper hypodermis of 'Prata-Anã' banana plants rooted in a growth chamber (artificial light) was also observed by Rocha (2005). Regarding the characteristics of the stomata, the leaves of banana plants have stomata distributed on both faces of the epidermis, however, with greater number on the lower face (Table 3), condition that classifies this species as amphistomatic, which agreed with Sandoval et al. (1994) and Rocha (2005).

Greater number of stomata per $\mathrm{mm}^{-2}$ was observed in the lower hypodermis in the natural environment, only with $30 \mathrm{~g} \mathrm{~L}^{-1}$ sucrose $(p \leq 0.05)$. In contrast, no effect for the factors studied was observed

Table 2 - Tissue width and stomata density in micropropagated 'Caipira' (AAA) banana plants as a function of cultivation environment and sucrose concentration.

\begin{tabular}{|c|c|c|c|c|c|c|c|}
\hline Sucrose & $\begin{array}{l}\text { Epidermis } \\
\text { upper }\end{array}$ & $\begin{array}{c}\text { Palisade } \\
\text { parenchyma }\end{array}$ & $\begin{array}{c}\text { Spongy } \\
\text { parenchyma }\end{array}$ & $\begin{array}{l}\text { hypodermis } \\
\text { lower }\end{array}$ & $\begin{array}{c}\text { Epidermis } \\
\text { lower }\end{array}$ & $\begin{array}{c}\text { Foliar } \\
\text { limb }\end{array}$ & $\begin{array}{c}\text { Stomate } \\
\text { density upper }\end{array}$ \\
\hline \multicolumn{8}{|l|}{$\mathrm{g} \mathrm{L}^{-1}$} \\
\hline 15 & $20.5 \mathrm{a}$ & $58.1 \mathrm{a}$ & $76.7 \mathrm{a}$ & $47.7 \mathrm{a}$ & $13.7 \mathrm{a}$ & $278.6 \mathrm{a}$ & $32.2 \mathrm{a}$ \\
\hline 30 & $16.7 \mathrm{~b}$ & $60.4 \mathrm{a}$ & $72.6 \mathrm{a}$ & $49.1 \mathrm{a}$ & $13.3 \mathrm{a}$ & $266.5 \mathrm{~b}$ & $34.6 \mathrm{a}$ \\
\hline \multicolumn{8}{|l|}{ Environment } \\
\hline Natural & $17.8 \mathrm{~b}$ & $67.3 \mathrm{a}$ & $82.4 \mathrm{a}$ & $46.6 \mathrm{~b}$ & $11.9 \mathrm{~b}$ & $272.7 \mathrm{a}$ & $35.6 \mathrm{a}$ \\
\hline Artificial & $19.4 \mathrm{a}$ & $51.1 \mathrm{~b}$ & $67.0 \mathrm{~b}$ & $50.2 \mathrm{a}$ & $15.1 \mathrm{a}$ & $272.4 \mathrm{a}$ & $31.3 \mathrm{a}$ \\
\hline CV (\%) & 12.47 & 13.11 & 15.50 & 11.24 & 17.73 & 6.45 & 27.40 \\
\hline
\end{tabular}

Means followed by distinct letters in the vertical, within each variable, are different ( $\mathrm{F}$ test at $5 \%$ ).

Table 3 - Width of the upper hypodermis and stomata density of the lower hypodermis 'Caipira' (AAA) micropropagated banana plants as a function of the cultivation environment and sucrose concentration.

\begin{tabular}{|c|c|c|c|c|c|c|}
\hline \multirow{2}{*}{ Sucrose } & \multicolumn{2}{|c|}{ Hypodermis upper } & \multirow{2}{*}{ Mean } & \multicolumn{2}{|c|}{ Stomata density lower } & \multirow{2}{*}{ Mean } \\
\hline & Natural & Artificial & & Natural & Artificial & \\
\hline $\mathrm{g} \mathrm{L}^{-1}$ & \multicolumn{6}{|c|}{ - } \\
\hline 15 & $44.1 \mathrm{Ba}$ & $79.7 \mathrm{Aa}$ & $61.9 \mathrm{a}$ & $158.1 \mathrm{Aa}$ & $150.7 \mathrm{Aa}$ & $154.4 \mathrm{a}$ \\
\hline 30 & $49.5 \mathrm{Ba}$ & $59.7 \mathrm{Ab}$ & $54.6 \mathrm{~b}$ & $167.2 \mathrm{Aa}$ & $131.1 \mathrm{Bb}$ & $149.2 \mathrm{a}$ \\
\hline Mean & $46.8 \mathrm{~B}$ & $69.7 \mathrm{~A}$ & & $162.6 \mathrm{~A}$ & $140.9 \mathrm{~B}$ & \\
\hline $\mathrm{CV}(\%)$ & \multicolumn{2}{|c|}{11.97} & & \multicolumn{2}{|c|}{12.43} & \\
\hline
\end{tabular}

Means followed by distinct letters, small caption in the vertical and capital in the horizontal, within each variable, are different (F test at $5 \%$ ). 
on the upper surface (Table 3). Similar results were obtained by Rocha (2005) for the 'Prata-Anã' cultivar that showed greater stomata density on the lower surface in artificial environment with $15 \mathrm{~g} \mathrm{~L}^{-1}$ and natural with $15 \mathrm{~g} \mathrm{~L}^{-1}$ or $30 \mathrm{~g} \mathrm{~L}^{-1}$ sucrose. Similar effect of irradiance was also observed by Deccetti (2004) in Annona glabra plants subjected to in vitro rooting. The increase in stomata density can provide the plant with increased gas conductance, thus avoiding that photosynthesis to be limited under different environmental conditions (Kundu \& Tigerstedt, 1998). Nevertheless, the occurrence or not of differences in the number of stomata depends on the species and the cultivation condition.

\section{Ex vitro survival}

Thirty days after transplanting, 100\% survival was recorded in plants from the natural environment, in both sucrose concentrations. Conversely, in plants from the artificial environment, losses of $28.0 \%$ and $6.3 \%$ were observed with $15 \mathrm{~g} \mathrm{~L}^{-1}$ and $30 \mathrm{~g} \mathrm{~L}^{-1}$ of carbohydrate, respectively (Table 4).

Possibly, the exposure of the shoots to greater irradiance and temperature amplitudes promoted the hardening of the plants still in vitro, since the greenhouse conditions were more similar to that in which the plants were acclimatized, thus favoring lower stress in the transplanting and the ex vitro reestablishment.

Actually, the modifications observed to the RWC and anatomic parameters under natural light confirm the better structural and physiological adaptation of the plants and justify the greater survival rates. Moreover, these results are consistent with those obtained by Kodym \& Zapata-Arias (1999) in Musa cv. Grande Naine (AAA), and Talavera et al. (2005) in Cocos nucifera plants grown under natural light. Moreover, according to Kodym \& Zapata-Arias (1999), plants grown under natural light were successfully hardened, with $100 \%$ survival after two months, and presented normal development.

Table 4 - Survival of 'Caipira' (AAA) micropropagated banana plants as a function of the cultivation environment and sucrose concentrations, 30 days after the ex vitro transplanting.

\begin{tabular}{|c|c|c|c|}
\hline \multirow{2}{*}{ Environment } & \multicolumn{2}{|c|}{ Sucrose $\left(\mathrm{g} \mathrm{L}^{-1}\right)$} & \multirow[t]{2}{*}{ Mean } \\
\hline & 15 & 30 & \\
\hline & \multicolumn{3}{|c|}{ - } \\
\hline Natural & 100.0 & 100.0 & 100.0 \\
\hline Artificial & 72.0 & 93.7 & 82.9 \\
\hline Mean & 86.0 & 96.9 & \\
\hline
\end{tabular}

Data obtained by the rate between the number of dead plants and or not developed and the total number of plants transferred to the ex vitro conditions, not being statistically analyzed.
The effect of sucrose on the success plant hardening is reported by Folliot \& Marchal (1992), Skrebsky et al. (2004) and Pacheco et al. (2006) for Musa spp., Pfaffia glomerata Spreng. Pedersen and Arachis retusa, using between $15 \mathrm{~g} \mathrm{~L}^{-1}$ and $60 \mathrm{~g} \mathrm{~L}^{-1}$. In contrast, negative effects from the partial or total removal of sucrose on the ex vitro development of micropropagated plants were obtained by Skrebsky et al. (2004), Fuentes et al. (2005) and Pacheco et al. (2006). The low survival and the slow development of Cocos nucifera L. cultivated under the absence or low sucrose concentration is a result of the deficiency in the formation of carbon backbone and the allocation of the stocks from the leaves formed in vitro to sustain the ex vitro reestablishment (Fuentes et al., 2005).

With a profound knowledge of the physiological and structural alterations induced in vitro, it is possible to establish strategies for the most efficient manner of transferring micropropagated plants to ex vitro conditions and, consequently, to maximize survival rates (Smith et al., 1997; Apóstolo et al., 2005). Thus, the results obtained in this study provide an explanation for the high survival rate observed in plants grown in natural light and contributes for the use of this kind of lighting for in vitro establishment. Similarly, the association of survival rate with morphological and anatomical features is important to demonstrate or not the hardening of plants subjected to modifications in the in vitro environment, thus reducing the losses after the exposition to the ex vitro environment (Capellades et al., 1990).

\section{CONCLUSIONS}

In vitro rooting of 'Caipira' banana shoots, under natural lighting, with $15 \mathrm{~g} \mathrm{~L}^{-1}$ or $30 \mathrm{~g} \mathrm{~L}^{-1}$ sucrose promoted the thickening of the palisade and spongy parechyma, reduced leaf water loss, and increased ex vitro plant survival.

The study of structural and physiological characteristics provided a better understanding of the changes in banana plants subjected to environmental alterations in in vitro cultivation.

Substituting fluorescent lights for natural lighting, during in vitro rooting confirms the potential of this lighting source in banana micropropagation protocols.

\section{ACKNOWLEDGMENTS}

To Conselho Nacional de Desenvolvimento Científico e Tecnológico (CNPq) for the financial support and the fellowship for the first author. 


\section{REFERENCES}

AMÂNCIO, S.; REBORDÃO, J.P.; CHAVES, M.M. Improvement of acclimatization of micropropagated grapevine: photosynthetic competence and carbon allocation. Plant Cell, Tissue and Organ Culture, v.58, p.31-37, 1999.

APÓSTOLO, N.M.; BRUTTI, C.B.; LLORENTE, B.E. Leaf anatomy of Cynara scolymus L. in successive micropropagation stages. In Vitro Cellular Development Biology - Plant, v.41, p.307-313, 2005.

ARNON, D.I. Copper enzymes in isolated choroplasts. Polyphenoloxidase in Beta vulgaris. Plant Physiology, v.24, p.1-15, 1949.

ATROCH, E.M.A.C.; SOARES, A.M.; ALVARENGA, A.A.; CASTRO, E.M. Crescimento, teor de clorofilas, distribuição de biomassa e características anatômicas de plantas jovens de Bauhinia forficata Link. submetidas a diferentes condições de sombreamento. Ciência e Agrotecnologia, v.25, p.853-862, 2001.

CAPELlADES, M.; FONTARNAU, R.; CARULLA, C.; DEBERGH, P. Environment influences anatomy of stomata and epidermal cells in tissue-cultured Rosa multiflora. Journal of the American Society for Horticultural Science, v.115, p.141$145,1990$.

CASTRO, E.M.; PINTO, J.E.B.P.; MELO, H.C.; SOARES, A.M.; ALVARENGA, A.A.; LIMA JÚNIOR, E.C. Aspectos anatômicos e fisiológicos de plantas de guaco submetidas a fotoperíodos. Horticultura Brasileira, v.23, p.846-850, 2005.

DECCETTI, S.F.C. Ambiente de cultivo e respostas morfofisiológicas durante o processo de micropropagação de Annona glabra L. Lavras: Universidade Federal de Lavras, 2004. 93p. Tese (Doutorado).

FERREIRA, D.F. SISVAR 4.3: sistema de análise estatística. Lavras: UFLA/DEX, 2000.

FOLLIOT, M.; MARCHAL, J. Croissance in vitro des bananiers: influence de la concentration en saccharose du milieu de culture sur le développement des plants du cultivar Petite Naine. Fruits, v.47, p.649-655, 1992.

FUENTES, G.; TALAVERA, C.; OROPEZA, C.; DESJARDINS, Y.; SANTAMARÍA, J.M. Exogenous sucrose can decrease in vitro photosynthesis but improve field survival and growth of coconut (Cocos nucifera L.) in vitro plantlets. In Vitro Cellular \& Developmental Biology-Plant, v.41, p.69-76, 2005.

GÜBBÜK, H.; PEKMEZCI, M. In vitro propagation of some new banana types (Musa spp.). Turkish Journal of Agriculture and Forestry, v.28, p.355-361, 2004.

HANBA, Y.T.; KOGAMI, H.; TERASHIMA, L. The effects of growth irradiance on leaf anatomy and photosynthesis in Acer species differing in light demand. Plant Cell and Enviroment, v.25, p.1021-1030, 2002.

HAZARIKA, B.N. Morpho-physiological disorders in in vitro culture of plants. Scientia Horticulturae, v.108, p.105-120, 2006.

HAZARIKA, B.N. Acclimatization of tissue-cultured plants. Current Science, v.85, p.1704-1712, 2003.

JOHANSEN, B.A. Plant microtechnique. New York: McGrawHill, 1940. 523p.

KHAN, P.S.S.V.; EVERS, D.; HAUSMAN, J.F. Stomatal characteristics and water relations of in vitro grown Quercus robur NL 100 in relation to acclimatization. Silvae Genetica, v.48, p.83-87, 1999.

KITAJIMA, K.; HOGAN, K.P. Increases of chlorophyll a/b ratios during acclimatization of tropical woody seedlings to nitrogen limitation and high light. Plant Cell and Environment, v.26, p.857-865, 2003.

KODYM, A.; ZAPATA-ARIAS, F.J. Natural light as an alternative light source for the in vitro culture of banana (Musa acuminata cv. 'Grande Naine') Plant Cell, Tissue and Organ Culture, v. 55, p.141-14, 1999.
KRAUS, J.E.; ARDUIM, M. Manual básico de métodos em morfologia vegetal. Rio de Janeiro: EDUR, 1997. 198p.

KUNDU, S.K.; TIGERSTEDT, P.M.A. Variation in net photosynthesis, stomate characteristics, leaf area and whole plant phytomass production among ten provenances of neem (Azadirachta indica). Tree Physiology, n.19, p.47-52, 1998.

LABOURIAU, L.G.; OLIVEIRA, J.G.; SALGADOLABOURIAU, M.L. Transpiração de Schizolobium parahyba (Vell) Toledo I. Comportamento na estação chuvosa, nas condições de Caeté, Minas Gerais. Anais da Academia Brasileira de Ciência, v.33, p.237-257, 1961.

LAMHANEDI, M.; CHAMBERLAND, H.; TREMBLAY, F.M. Epidermal transpiration, ultrastuctural characteristics and net photosynthesis of white spruce somatic seedlings in response to in vitro acclimatization. Physiologia Plantarum, v.118, p.554-561, 2003.

LARCHER, W. Ecofisiologia vegetal. São Carlos: Rima, 2000. $531 \mathrm{p}$.

LEE, D.W.; OBERBAUER, S.F.; JOHNSON, P.; KRISHNAPILAY, B.; MANSOR, M.; MOHAMAD, H.; YAP, S.K. Effects of irradiance and spectral quality on leaf structure and function in seedlings of two Southeast Asian hopea (Dipterocarpaceae) species. American Journal of Botany, v.87, p.447-455, 2000 .

MOHAMMED, G.H.; VIDAVER, W.E. The influence of acclimatization treatment and plantlet morphology on early greenhouse-performance of tissue-cultured Douglas fir [Pseudotsuga menziesii (Mirb.) Franco]. Plant Cell, Tissue and Organ Culture, v.21, p.111-117, 1990.

MURASHIGE, T.; SKOOG, F.A. A revised medium for rapid growth and bioassays with tobacco tissue cultures. Physiologia Plantarum, v.15, p.473-497, 1962.

NAVARRO, C.; TEISSON, C.; CÔTE, F.; GANRY, J. Effects of light intensity and $\mathrm{CO}_{2}$ concentration on growth of banana plants (Musa AAA, cultivar 'Petite Naine') in vitro and subsequent growth following acclimatization. Scientia Horticulturae, v.60, p.41-54, 1994.

PACHECO, G.; GAGLIARDI, R.F.; COGLIATTI, M.B.; MANHÃES, H.B.; CARNEIRO, L.A.; VALLS, J.F.M.; MANSUR, E. Influence of substrates and in vitro preconditioning treatments on ex vitro acclimatization of Arachis retusa. Pesquisa Agropecuária Brasileira, v.41, p.165-169, 2006.

ROCHA, H.S. Luz e sacarose na micropropagação da bananeira "Prata Anã": alterações morfoanatômicas. Lavras: Universidade Federal de Lavras, 2005. 98p. Dissertação (Mestrado).

ROMANO, A.; MARTINS-LOUÇÃO, M.A. Water loss and morphological modifications in leaves during acclimatization of cork oak micropropagated plantlets. Acta Horticulturae, v.616, p.439-442, 2003.

SANDOVAL, J.A.; MÜLLER, L.E.; WEBERLING, F. Foliar morphology and anatomy of Musa cv. Grande Naine (AAA) plants grown in vitro and during hardening as compared to fieldgrown plants. Fruits, v.49, p.37-46, 1994

SCIUTTI, R.; MORINI, S. Water loss and photosynthesis of plum plantlets is influenced by relative humidity during rooting in vitro. Journal of Horticultural Science, v.10, p.221-228, 1995.

SERRET, M.D.; TRILLAS, M.I. Effects of light and sucrose levels on the anatomy, ultrastructure, and photosynthesis of Gardenia jasminoides Ellis leaflets cultured in vitro. International Journal of Plant Science, v.161, p.281-289, 2000.

SHACKEL, K.A.; NOVELLO, V.; SUTTER, E.G. Stomatal function and cuticular conductance in whole tissue cultured apple plants. Journal of American Society Horticultural, v.115, p.468472, 1990.

SILVA, A.B. Biorreatores e luz natural na micropropagação do abacaxizeiro. Lavras: Universidade Federal de Lavras, 2006. 132p. Tese (Doutorado). 
SKREBSKY, E.C.; NICOLOSO, F.T; FERRÃO, G.E. Sacarose e período de cultivo in vitro na aclimatização ex vitro de ginseng brasileiro (Pfaffia glomerata Spreng. Pedersen). Ciência Rural, v.34, p.1471-1477, 2004.

SMITH, W.K.; VOGELMANN, T.C.; DELUCIA, E.H.; BELL, D.T.; SHEPHERD, K.A. Leaf form and photosynthesis. BioScience, v.47, p.785-793, 1997.

SUTTER, E.G.; SHACKEL, K.; DIAZ, J.C. Acclimatization of tissue cultured plants. Acta Hoticulturae, v.314, p.115-119, 1992.

TALAVERA, C.; CONTRERAS, F.; ESPADAS, F.; FUENTES, G.; SANTAMARÍA, J.M. Cultivating in vitro coconut palms (Cocos nucifera) under glasshouse conditions with natural light, improves in vitro photosynthesis nursery survival and growth. Plant Cell, Tissue and Organ Culture, v.83, p.287-292, 2005.

VALERO-ARACAMA, C.; WILSON, S.B.; KANE, M.E.; PHILMAN, N.L. Influence of in vitro growth conditions on in vitro and ex vitro photosynthetic rates of easy- and difficult-toacclimatize sea oats (Uniola paniculata L.) genotypes. In Vitro Cellular Development Biology - Plant, v.43, p.237-246, 2007 .
YOKOTA, S.; KARIM, M. Z.; AZAD, M.A.K.; RAHMAN, M.M.; EIZAWA, J.; SAITO, Y.; ISHIGURI, F.; IIZUKA, K.; YAHARA, S.; YOSHIZAWA1, N. Histological observation of changes in leaf structure during successive micropropagation stages in Aralia elata and Phellodendron amurense. Plant Biotechnology, v.24, p.221-226, 2007.

Whatley, F.H.; Whatley, F.R. A Luz e a vida das plantas. São Paulo: EPU-EDUSP, 1982. 101 p. (Temas de Biologia, 30).

Received October 22, 2007

Accepted October 06, 2008 